\title{
Study of biomechanical overload in urban gardeners of Barcelona: application of analytical models for risk exposure evaluation in annual working cycle
}

\author{
Alvarez-Casado, Enrique ${ }^{\mathrm{a},{ }^{*}}$, Hernandez-Soto, Aquiles $^{\mathrm{b}}$, Tello, Sandoval $^{\mathrm{b}}$ and Gual, Rosa ${ }^{\mathrm{a}}$ \\ ${ }^{a}$ Departament d'Organització d'Empreses (DOE), Universitat Politècnica de Catalunya (UPC), Av. Diagonal, \\ 647, Pl 7, 08028, Barcelona, Spain. \\ ${ }^{\mathrm{b}}$ Centro de Ergonomia Aplicada (cenea), C. Cardenal Reig 23, 08028, Barcelona, Spain.
}

\begin{abstract}
Occupational musculoskeletal disorders in the upper limbs and its consequences on the impact and prevalence in the work force are subject of many investigations in almost all the production fields. However, the exposure to this kind of risk factor on urban gardeners has not been well studied so far. The kind of plant varieties used in the parks, the tools that they use, as much as the necessary actions for the maintenance of the park, have an impact on the biomechanical overload of the upper limbs. Additionally, the analysis of the exposure to the biomechanical overload on upper limbs in gardening work is a complex task, mainly because it is an activity highly variable and of annual cycle. For this reason an analytical model for risk exposure evaluation is necessary. During this research the work activity of 29 gardeners in 3 urban parks of Barcelona has been analyzed. Each park has a specific acting plan, in relation with the quantity and the typology of vegetal species, its classification and the season of the year. Work and observation and video recording sessions on-site were conducted. The video-graphic registration was done on workers without any prior musculoskeletal disorder and with a minimum labour experience of 5 years. Moreover, the analysis of saturation time, considered as the relation of the repetitive working hours in reference with the hours of effective work was done. Using the registered tasks on video, the biomechanical overload on upper limbs applying the OCRA Checklist method was analyzed. Results: A methodological procedure to analyze the risk exposure in annual working cycle has been proposed. The results that we got allow us to get information that can help in the assignment of the tasks and in the training of staff, as well as in the recommendations of the urban landscape's design. All these aspects have the goal to decrease the risk to develop work-related musculoskeletal disorders
\end{abstract}

Keywords: Gardening, biomechanics, risk exposure, highly variable exposure, musculoskeletal disorders, annual cycle.

\section{Introduction}

The concept of garden as a space where to cultivate plants is probably as ancient as human settlements, even though for many centuries it was used more as a status symbol, in order to show ones power and wealth. We have clear examples of this in Europe, dating as far back as the Renaissance. The concept of garden as a place for the entertainment of senses is without any doubt more recent. Since the beginning of XX century gardens are an integrative part of the city.

The landscape gardening is a new discipline of the urban agriculture (an agricultural practice that is made inside or on the outskirts of an urban area). This kind of gardening is based on the cultivation of plants, as an ornamental function; the economic goal is not as important as in the traditional agriculture. Some examples of spaces used for the landscape gardening are public and private parks, courtyard and gardens.

\footnotetext{
*Corresponding author. E-mail: enrique.alvarez@upc.edu.
} 
The urban gardening is a practice that grew significantly in the last couple of years, due to an increase in the quality of life and to a higher environmental consciousness. The International Health Organization recommendation for the cities is to dispose a minimum of 10 to $15 \mathrm{~m} 2$ of green space per habitant. In the last years, the surface of green areas in Barcelona has increased about $12 \%$, and today it gets an actual ratio of $17,3 \mathrm{~m} 2$ per habitant of green and natural areas.

Gardeners take care of the grass and of the plantation of various kinds of plants annually (plants for garden) and of the plantation and the maintenance of bushes and trees [1]. This kind of tasks makes gardening an activity where the labour force is a real important and essential component.

The kind of works that gardening requires in a park can vary according to the period of the year and the vegetal status of the plants. In this research we present the characterization of the exposure to the biomechanical overload in upper limbs during the annual cycle of the gardeners that are in charge of the maintenance of three parks in the city of Barcelona.

\section{Methodology}

In this research we analyzed the activity of a total of 29 gardeners that are in charge of the maintenance of 3 urban parks of Barcelona (see Table 1), in a range of age between 20 and 55 years old (see Table 2).

The working day of the gardeners is 7 hours, from 8.00 to 15.00 .

They have a break for half an hour, between 10.00 and 10.30. The time that they use to move through the park to get the working place is approximately 15 minutes at the beginning of the day, and 15 minutes at the end of the day.

They work 5 days per week, from Monday to Friday, for a total of 35 hours per week and 1549 hours per year.

Park A has a surface of 17,43 hectares and it has a large grass area and big walk paths; park B has a surface of 3,16 hectares and it is rich of parterres with rosebushes; park $\mathrm{C}$ has a surface of 1,65 hectares and is rich of big hedges, vegetables and bindweeds.

Table 1

Number of gardeners for sex

\begin{tabular}{|c|c|c|c|c|}
\hline Gardeners per sex & Park A & Park B & Park C & Total \\
\hline Number of men & 11 & 4 & 7 & 22 \\
\hline Number of women & 5 & 2 & 0 & 7 \\
\hline Total & 16 & 6 & 7 & 29 \\
\hline
\end{tabular}

Once the necessary administrative permissions to develop the research have been obtained, interview with people in charge of each park was contacted in order to explain the goal of this study and the content of the working sessions on-site. All of them accepted to collaborate and gave us their complete consent.

\section{Table 2}

Distribution of gardeners per parks, according to age range

\begin{tabular}{|c|c|c|c|c|}
\hline Gardeners per age & Park A & Park B & Park C & Total \\
\hline $20-30$ years & 1 & 0 & 1 & 2 \\
\hline$>30-45$ years & 9 & 3 & 4 & 16 \\
\hline$>45$-55 years & 6 & 3 & 2 & 11 \\
\hline$>55$ years & 0 & 0 & 0 & 0 \\
\hline Total & 16 & 6 & 7 & 29 \\
\hline
\end{tabular}

Thanks to interviews conducted on the participants in charge of the organization of each park, information about working organization, assignment of tasks amongst the group of gardeners and temporal planning were collected.

Working sessions on-site were made: an industrial engineer with a previous training observed and registered the labour activities on video. Workers with no musculoskeletal disorders and with a minimum working experience of 5 years were selected for video registering.

A video registration of a minimum of 10 minutes with non-stop was made for each task, even if the work was really repetitive, in order to be sure to represent a high number of postures and movements that they require during their job. For each task, a minimum of three different workers were registered with the goal to identify the more frequent working habits.

Planning of the working sessions on-site was organized with the person in charge of the work of each park with the main goal to observe different tasks or conditions. The planning was altered in many occasions, due to meteorological reasons, to machines or tools' availability and to the change of organizational requirements.

In fact, the bad meteorological conditions can cause the change of some programmed tasks. For example, when it rains, they work on tools' cleaning task; when there is strong wind, they remove fallen trees and when it snows, they remove the snow from the points of access to the park. In our research we did not take in consideration these unplanned tasks.

Once the tasks were defined, the filming files were edited in order to finally get video-archives that could represent each activity with duration of approximately 1 minute.

Using these videos, the analysis of the biomechanical overload in upper limbs, applying the OCRA Checklist method [2] was done. The 
Checklist method [2] was done. The application of this method to similar activities as agriculture has been published in some papers $[3,4]$.

In reference to the information related with the time of exposure to each one of the tasks, we extracted them from the daily register that the manager of each park prepares. In order to characterize the exposure of a whole year, we used the register of the year 2009.

\section{Results}

Each park is associated with a specific action plan, according to the quantity and the typologies of vegetal species, its classification and the year season.

In tables 3, 4, 5 the hours per month that the gardeners dedicate to each task for every park are shown.

Due to the variability of the work planning, it was not possible to shoot all the tasks, which have been accomplished during the year. However, the tasks that we analyzed represent the $80 \%$ of the working time during the year (See Table 6).

Table 3

Monthly hours dedicated to each task in park A, year 2009.

\begin{tabular}{|c|c|c|c|c|c|c|c|c|c|c|c|c|c|}
\hline Park A & Jan & Feb & Mar & Apr & Mav & Jun & Jul & Ago & Sep & Oct & Nov & Dec & Total \\
\hline To provide compost and substrates & & 22 & & & 18 & & & & & 12 & 35 & & 87 \\
\hline To bring bark of pine & & & & & & & & & & & & & 0 \\
\hline To change and collocate earth & & & & & & & & & & & & & 0 \\
\hline To hoe manually & & & & & 3 & & 4 & 2 & & 6 & 12 & & 27 \\
\hline To hoe mechanically & & 4 & 48 & & 22 & 20 & 10 & 5 & & 6 & 17 & & 132 \\
\hline To plant trees in areas & & & & 5 & & & & 18 & 8 & 2 & & & 33 \\
\hline To plant trees in lining up & & 23 & & 1 & & 4 & & & & 5 & & & 33 \\
\hline To plant flowers' plant & 5 & 24 & 24 & 44 & 188 & & & 35 & 106 & 4 & 122 & & 552 \\
\hline To plant other vegetables & & 60 & 24 & & 28 & 5 & 44 & & 9 & 24 & 4 & & 198 \\
\hline Grass: to cut & 8 & 92 & 134,5 & 199,5 & 129 & 119 & 186 & 150 & 135 & 88 & 116 & 38 & 1395 \\
\hline Grass: to sow & & & 15 & & & & 1 & & & 3 & & & 19 \\
\hline Grass: to fill holes & & & & & & & & & & 9 & 5 & & 14 \\
\hline Grass: to scarify & & & 202 & & & & & & & & & & 202 \\
\hline Grass: to remove garbage and vegetation & 45,5 & 54 & & 82 & 61 & 50 & 82 & 76 & 71 & 46 & 49 & 101 & 717,5 \\
\hline To clean green surfaces & 80 & 80 & 87 & 111 & 103 & 112 & 126 & 138 & 113 & 118 & 152 & 142 & 1362 \\
\hline To clean sand and pavement & 216 & 130,5 & 131,5 & 92 & 107 & 99 & 106 & 95 & 116 & 124 & 188 & 149 & 1554 \\
\hline To clean lakes & 3 & 12 & 2 & 2,5 & 128 & & 1 & & 3,5 & 4,5 & 2,5 & 1,5 & 160,5 \\
\hline To clean hut & & 2 & 9,5 & 11,5 & 3 & 1 & 8,5 & 6 & 2 & 2 & 1 & 10 & 56,5 \\
\hline To clean tree wells & & 26 & & & & & & & & & & & 26 \\
\hline To prone trees in areas & 10 & & & 15 & 3 & & & 4 & & & & & 32 \\
\hline To prone trees lining up & & & 8 & & & 3 & & & & & & & 11 \\
\hline To prone hedges, bushes... & 364 & 308,5 & 22 & & 96 & 142 & 362 & 198 & 40 & 100 & 166 & 225,5 & 2024 \\
\hline To pull up trees & & & & 1 & & & & 2 & & & & & 3 \\
\hline To pull up other vegetables & 2 & 4 & & 101 & & & & 73 & & 42 & 9 & & 231 \\
\hline Mounting irrigation system & & & & & & & & & & & & & 0 \\
\hline Irrigation by sprinkler & & 6 & 66 & 12 & 4 & 6,5 & 11 & 48 & 30 & 4 & & & 187,5 \\
\hline Irrigation by hose & 23 & 55 & 73,5 & 17 & 68 & 159 & 81 & 161 & 39 & 36 & 55 & 14 & 781,5 \\
\hline Light digging & 68 & 172 & 137 & 173 & 115 & 151,5 & 76 & 27 & 49 & 119 & 48 & 3 & 1138,5 \\
\hline To remove weeds & 4 & 42 & 222 & 33 & 82 & 19 & 87 & 5 & 118 & 44 & 28 & 23,5 & 707,5 \\
\hline To ring out & 14 & 1 & & & 24 & 3 & & & & & & & 42 \\
\hline To polish and to put in order the sand & 18 & & 88 & & 8 & & 18 & & 65 & & 29 & 10 & 236 \\
\hline Weedkiller treatment and to fence & & & 12 & 6 & 18 & & & & & & 16 & & 52 \\
\hline To pick up and to transport garbage & 273 & 165 & 168 & 123 & 169 & 135,5 & 196 & 138 & 176 & 152 & 192 & 156,5 & 2044 \\
\hline To move from one place to another & & & & & & & 0,5 & & & & & & 0,5 \\
\hline Supervision and control & 117 & 114 & 114,5 & 63 & 65,5 & 71 & 67 & 64 & 29 & 27 & 23,5 & 20 & 775,5 \\
\hline Different repairs & 50,5 & 29 & 57,5 & 56 & 36,5 & 110 & 64 & 57 & 40,5 & 9,5 & 13,5 & 32,5 & 556,5 \\
\hline Specific: to open the park & & 32 & & 13 & 10 & 11,5 & 11 & 16 & 12 & 3 & 13 & 19 & 140,5 \\
\hline Specific: to dismount manger & 44,5 & & & & & & & & & & & & 44,5 \\
\hline Specific: to place sward & & & 283 & & & & & & & & & & 283 \\
\hline Specific: greenhouse & & & & & & & & & & 37 & & 105 & 142 \\
\hline Others & 11 & & 21 & 36 & & & 23 & 3 & 16 & 62 & 15,5 & & 187,5 \\
\hline TOTAL Hours of work & 1357 & 1458 & 1950 & 1198 & 1489 & 1222 & 1565 & 1321 & 1178 & 1089 & 1312 & 1051 & 16188,5 \\
\hline TOTAL Other hours & 463,5 & 648 & 559 & 1052 & 831,5 & 955,5 & 1080,5 & 999,5 & 973,5 & 1100,5 & 765,5 & 1134 & 10562 \\
\hline TOTAL Hours per month & 1820 & 2106 & 2509 & 2249 & 2320,5 & 2177,5 & 2645,5 & 2320,5 & 2151,5 & 2189,5 & 2077,5 & 2184 & 26750,5 \\
\hline
\end{tabular}


Table 4

Monthly hours dedicated to each task in park B, year 2009.

\begin{tabular}{|c|c|c|c|c|c|c|c|c|c|c|c|c|c|}
\hline Park B & Jan & Feb & Mar & Apr & May & Jun & $\mathrm{Jul}$ & Ago & Sep & Oct & Nov & Dec & Total \\
\hline To provide compost and substrates & 15 & & & & & & & & & & & & 15 \\
\hline To bring Bark of Pine & 46,5 & 67,5 & 44 & 32,5 & & & & & & & & 9 & 199,5 \\
\hline To change and collocate earth & & & 98 & 16 & & & & & & & & & 114 \\
\hline To hoe manually & & & & & & & & & & & & & 0 \\
\hline To hoe mechanically & 4 & 10 & & & & & & & & & 12 & & 26 \\
\hline To plant trees in areas & & 11 & 5 & & 4 & & & & & & & & 20 \\
\hline To plant trees in lining up & & & & & & 12 & & & & & & & 12 \\
\hline To plant flowers' plant & & 59 & 25 & 6 & & & & & & & 9,5 & & 99,5 \\
\hline To plant other vegetables & 11 & & 63 & & 13 & & 9 & & & & & & 96 \\
\hline Grass: to cut & 4 & 4 & 78 & 76 & 112 & 115 & 105 & 120 & 81 & 67 & 38,5 & & 800,5 \\
\hline Grass: to sow & & & & & & & & & & & & & 0 \\
\hline Grass: to fill holes & & 28,5 & & & & & & & & & & & 28,5 \\
\hline Grass: to scarify & & & & & & & & & & & & & 0 \\
\hline Grass: to remove garbage and vegetation & 2 & 7,5 & 24,5 & 48,5 & 39 & 21 & 58 & 22 & 26 & 18 & & & 266,5 \\
\hline To clean green surfaces & 33 & 29 & 26 & 21 & 30 & 22 & 27 & 25 & 22 & 26 & 36 & 32 & 329 \\
\hline To clean sand and pavement & 28 & 25 & 25 & 29 & 46 & 23 & 32 & 25 & 28 & 26,5 & 30,5 & 28 & 346 \\
\hline To clean lakes & & & & & & & & & & & & & 0 \\
\hline To clean hut & 8 & 8 & 8 & 10 & 6 & 8 & 10 & 8 & 8 & 10 & 9 & 10 & 103 \\
\hline To clean tree wells & & & & & & & & & & & & & 0 \\
\hline To prone trees in areas & & 4 & & & & & & & & & & & 4 \\
\hline To prone trees lining up & & 5 & & & & & & & & & & & 5 \\
\hline To prone hedges, bushes... & 264,5 & 186,5 & 21 & 83,5 & 75 & 131 & 151 & 39 & 47 & 214,5 & 227,5 & 324,5 & 1765 \\
\hline To pull up trees & & & & & & & & & & & & & 0 \\
\hline To pull up other vegetables & & & & & & & & & & & & & 0 \\
\hline Mounting irrigation system & & & & & & & & & & & & & 0 \\
\hline Irrigation by sprinkler & & & & & & & & & & & & & 0 \\
\hline Irrigation by hose & & & 23 & 3 & 8 & 13 & 13 & 2 & 4 & & & & 66 \\
\hline Light digging & 35 & 102,5 & 45,5 & 4 & & & & & & & & 60,5 & 247,5 \\
\hline To remove weeds & 4,5 & & 196,5 & 70 & 173,5 & 137,5 & 95,5 & 153,5 & 177 & 166,5 & 86,5 & 5 & 1266 \\
\hline To ring out & & & & & & & & & & & & & 0 \\
\hline To polish and to put in order the sand & 4 & 10 & & 3 & 50 & & 3 & & 4 & 18 & 15,5 & & 107,5 \\
\hline Weedkiller treatment and to fence & & & & 27 & & & & & & & & & 27 \\
\hline To pick up and to transport garbage & 67 & 61,5 & 63 & 41,5 & 60 & 42 & 46 & 47 & 41 & 48,5 & 51 & 41 & 609,5 \\
\hline To move from one place to another & & & & & & & & & & & & & 0 \\
\hline Supervision and control & 40 & 58,5 & 74,5 & 44 & 72 & 46 & 51 & 44 & 40 & 43 & 40 & 41 & 594 \\
\hline Different repairs & 6 & 13 & & & 47 & 18 & 7,5 & 8 & 12 & & 1 & & 112,5 \\
\hline Specific: to open the park & & & 66,5 & & & & & & & & & & 66,5 \\
\hline Specific: to dismount manger & 60,5 & & & & & & & & & & & & 60,5 \\
\hline Others & 51,5 & 6 & 6 & & & 4,5 & & & & 10 & 18 & 25 & 121 \\
\hline TOTAL Hours of work & 684,5 & 696,5 & 892,5 & 515 & 735,5 & 593 & 608 & 493,5 & 490 & 648 & 575 & 576 & 7507,5 \\
\hline TOTAL Other hours & 95,5 & 116 & 108,5 & 275 & 64 & 187 & 289 & 324,5 & 290 & 171 & 244 & 243 & 2407,5 \\
\hline TOTAL Hours per month & 780 & 812,5 & 1001 & 790 & 799,5 & 780 & 897 & 818 & 780 & 819 & 819 & 819 & 9915 \\
\hline
\end{tabular}

Table 5

Monthly hours dedicated to each task in park C, year 2009.

\begin{tabular}{|c|c|c|c|c|c|c|c|c|c|c|c|c|c|}
\hline 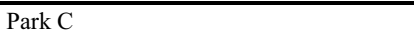 & Jan & Feb & Mar & $\mathrm{Apr}$ & May & Jun & Jul & Ago & Sep & Oct & Nov & Dec & Total \\
\hline To provide compost and substrates & & & & & & & & & & & & & 0 \\
\hline To bring Bark of Pine & & & 66 & 22,5 & & & & & & & & & 88,5 \\
\hline To change and collocate earth & & & & & & & & & & & & & 0 \\
\hline To hoe manually & & & & & & & & & & & & & 0 \\
\hline To hoe mechanically & & & & & & & & & & & & & 0 \\
\hline To plant trees in areas & & & & & & 12 & & & & & & & 12 \\
\hline To plant trees in lining up & 6 & & & 26 & & & & & & 2 & 18 & & 52 \\
\hline To plant flowers' plant & & & & & & & & 20 & 24 & & & & 44 \\
\hline To plant other vegetables & & 20 & 10 & & & 24,5 & & & 11 & 12 & & & 77,5 \\
\hline Grass: to cut & & 24 & 40 & 52 & 78,5 & 54,5 & 28 & 41 & 54 & 27,5 & & 26 & 425,5 \\
\hline Grass: to sow & & & & & & & & & & & & & 0 \\
\hline Grass: to fill holes & & & & & & & & & & & & & 0 \\
\hline Grass: to scarify & & & & & & & & & & & & & 0 \\
\hline Grass: to remove garbage and vegetation & 3 & 2 & 4 & 16 & 48 & 10,5 & 17 & 27,5 & 6 & & & & 134 \\
\hline To clean green surfaces & 70,5 & 78 & 73 & 62,5 & 68 & 62 & 48 & 8 & 52 & 78 & 149 & 58,5 & 807,5 \\
\hline To clean sand and pavement & 71 & 53,5 & 55 & 65 & 66 & 96,5 & 82 & 31 & 49 & 73 & 73 & 43 & 758 \\
\hline To clean lakes & & & & & & & & & & & & & 0 \\
\hline To clean hut & 8 & 3 & 2 & & & 2 & 3 & 1 & 2 & 6 & 4 & 11 & $\overline{42}$ \\
\hline To clean tree wells & & & & & & & & & & & & & 0 \\
\hline To prone trees in areas & & & & & & & & 2 & & & & & 2 \\
\hline To prone trees lining up & & & & & & & & & & & & & 0 \\
\hline
\end{tabular}




\begin{tabular}{|c|c|c|c|c|c|c|c|c|c|c|c|c|c|}
\hline To prone hedges, bushes... & 227 & 180,5 & 285 & 152 & 306,5 & 84,5 & & & 166,5 & 245 & 305,5 & 191,5 & 2144 \\
\hline To pull up trees & & & & & & & & & & & & & 0 \\
\hline To pull up other vegetables & 13 & & & & & & & 14,5 & & & & & 27,5 \\
\hline Mounting irrigation system & & 72 & & & & & & & & & & & 72 \\
\hline Irrigation by sprinkler & & 2 & 2 & & 12 & 14 & 45,5 & 62,5 & 15 & 12 & 15 & 4 & 184 \\
\hline Irrigation by hose & & 13,5 & 36 & & 21 & 30,5 & 152,5 & 160 & 53 & 15 & 11 & 2 & 494,5 \\
\hline Light digging & & & 47 & 47 & 24 & 43,5 & 93,5 & & 90,5 & 19 & & 2,5 & 367 \\
\hline To remove weeds & & 28 & & 52 & 4 & & & & 2 & 15,5 & & 25 & 126,5 \\
\hline To ring out & & & & & & & & & & & & & 0 \\
\hline To polish and to put in order the sand & & & & & & & & & & 16 & & & 16 \\
\hline Weedkiller treatment and to fence & & & & & & & & & & & & & 0 \\
\hline To pick up and to transport garbage & 136 & 116 & 126 & 94,5 & 115 & 107 & 112,5 & 56 & 102 & 11,5 & 122 & 98 & 1196,5 \\
\hline To move from one place to another & 21 & 21 & 22 & 17 & 19,5 & 18,5 & 21 & 8 & 18 & 19 & 20 & 16,5 & 221,5 \\
\hline Supervision and control & & 10 & 8 & & & 9 & & 7 & & 52 & 85 & 58 & 229 \\
\hline Different repairs & & & 8 & 4 & & 110 & 6 & 15 & & 7 & 9 & 6 & 165 \\
\hline Specific: emergencies with trees & 85 & 24 & 6 & & & & 5 & & & 2 & & & 122 \\
\hline Others & 10 & & & 5 & & 16 & 28 & & 3 & 32 & & & 94 \\
\hline TOTAL Hours of work & 650,5 & 647,5 & 790 & 615,5 & 762,5 & 695 & 642 & 453,5 & 648 & 644,5 & 811,5 & 542 & 7902,5 \\
\hline TOTAL Other hours & 129,5 & 262,5 & 211 & 294,5 & 186,5 & 241 & 398,5 & 502 & 372,5 & 233 & 144 & 413,5 & 3388,5 \\
\hline TOTAL Hours per month & 780 & 910 & 1001 & 910 & 949 & 936 & 1040,5 & 955,5 & 1020,5 & 877,5 & 955,5 & 955,5 & 11291 \\
\hline
\end{tabular}

Table 6

Working hours and percentage of representation

\begin{tabular}{|c|c|c|c|c|c|c|c|c|c|c|c|c|c|c|}
\hline \multicolumn{15}{|c|}{ Working hours and percentage of representation } \\
\hline \multicolumn{2}{|r|}{ Representation } & Jan & Feb & Mar & Apr & May & Jun & Jul & Ago & Sep & Oct & Nov & Dec & In the whole year \\
\hline \multirow{3}{*}{ 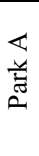 } & $\begin{array}{l}\text { Net time of repeti- } \\
\text { tive work (h) }\end{array}$ & 861 & 1118 & 1589 & 907 & 1208 & 894 & 1204 & 1043 & 905 & 836 & 1055 & 823 & 12443 \\
\hline & $\begin{array}{l}\text { Working time } \\
\text { studied (h) }\end{array}$ & 770 & 932 & 942 & 722 & 934 & 814 & 1033 & 816 & 814 & 645 & 916 & 643 & 9981 \\
\hline & $\%$ representation & 89,43 & 83,36 & 59,28 & 79,60 & 77,32 & 91,05 & 85,80 & 78,24 & 89,94 & 77,15 & 86,82 & 78,13 & 80,21 \\
\hline \multirow{3}{*}{ 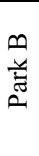 } & $\begin{array}{l}\text { Net time of repeti- } \\
\text { tive work (h) }\end{array}$ & 520 & 558 & 749 & 430 & 557 & 483 & 504 & 395 & 397 & 547 & 465 & 469 & 6074 \\
\hline & $\begin{array}{l}\text { Working time } \\
\text { studied (h) }\end{array}$ & 414 & 492 & 503 & 371 & 526 & 456 & 476 & 381 & 384 & 527 & 445 & 446 & 5421 \\
\hline & $\%$ representation & 79,62 & 88,17 & 67,16 & 86,28 & 94,43 & 94,41 & 94,44 & 96,46 & 96,73 & 96,34 & 95,70 & 95,10 & 89,25 \\
\hline \multirow{3}{*}{ 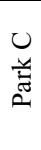 } & $\begin{array}{l}\text { Net time of repeti- } \\
\text { tive work (h) }\end{array}$ & 484 & 501 & 626 & 495 & 628 & 435 & 475 & 368 & 525 & 523 & 576 & 364 & 6000 \\
\hline & $\begin{array}{l}\text { Working time } \\
\text { studied }(\mathrm{h})\end{array}$ & 347 & 354 & 580 & 447 & 588 & 362 & 408 & 285 & 477 & 462 & 491 & 328 & 5129 \\
\hline & $\%$ representation & 71,69 & 70,66 & 92,65 & 90,30 & 93,63 & 83,22 & 85,89 & 77,45 & 90,86 & 88,34 & 85,24 & 90,11 & 85,48 \\
\hline
\end{tabular}

In Table 7, the temporal representation of the tasks analyzed over the time of exposure to repetitive work by each month is shown.

Moreover, we also did the analysis of saturation time, considered as the relation of the repetitive working hours in reference to the effective working hours (see Table 8). The un-saturation is due mainly to the time of training, sick leaves, permits, union activities and rain. In the same table the net time of repetitive work is shown, which corresponds to the time of effective work minor the dedication at no repetitive tasks [5], such as to pick up or to transport sacks, supervision, planning, moving from one place to the other, etc.

For each task the intrinsic risk level, considered as the risk level that a worker would have if he/she was exposed to the task for 420 minutes per day, for the duration of all working days was determined (see Table 9).

Table 7

Coverage of the study

\begin{tabular}{|c|c|c|c|c|c|c|c|c|c|c|c|c|}
\hline Coverage (\%) & Jan & Feb & Mar & Apr & May & Jun & Jul & Ago & Sep & Oct & Nov & Dec \\
\hline Park A & 85,4 & 82,7 & 90,3 & 96,4 & 92,7 & 88,4 & 88,4 & 81,6 & 93,4 & 91,9 & 81,5 & 81,4 \\
\hline Park B & 91,7 & 87,7 & 88,2 & 86,2 & 89,8 & 86,4 & 96,6 & 89,4 & 90,4 & 83,3 & 85,2 & 93,4 \\
\hline Park C & 99,1 & 95,6 & 99,3 & 87,6 & 87,6 & 84,1 & 96,6 & 98,6 & 88,9 & 89,9 & 97,8 & 98,6 \\
\hline
\end{tabular}


Table 8

Working and saturation time

\begin{tabular}{|c|c|c|c|c|c|c|c|c|c|c|c|c|c|}
\hline \multicolumn{2}{|c|}{ Work and saturation } & Jan & Feb & Mar & Apr & May & Jun & Jul & Ago & Sep & Oct & Nov & Dec \\
\hline & Total working time (h) & 1820 & 2106 & 2509 & 2249 & 2321 & 2178 & 2646 & 2321 & 2152 & 2170 & 2078 & 2184 \\
\hline & Effective working time (h) & 1357 & 1458 & 1950 & 1198 & 1489 & 1222 & 1565 & 1321 & 1178 & 1089 & 1312 & 1051 \\
\hline & Net time of repetitive work (h) & 861 & 1118 & 1589 & 907 & 1208 & 894 & 1204 & 1043 & 905 & 836 & 1055 & 823 \\
\hline & Saturation (\%) & 63,4 & 76,7 & 81,5 & 75,7 & 81,1 & 73,2 & 76,9 & 79 & 76,8 & 76,7 & 80,4 & 78,3 \\
\hline \multirow{4}{*}{$\begin{array}{l}\text { 象 } \\
\text { in }\end{array}$} & Total working time (h) & 780 & 812,5 & 1001 & 790 & 799,5 & 780 & 897 & 818 & 780 & 819 & 819 & 819 \\
\hline & Effective working time (h) & 684,5 & 696,5 & 892,5 & 515 & 735,5 & 593 & 608 & 493,5 & 490 & 648 & 575 & 576 \\
\hline & Net time of repetitive work ( & 520 & 558 & 749 & 430 & 557 & 483 & 504 & 395 & 397 & 547 & 465 & 469 \\
\hline & Saturation (\%) & 76 & 80 & 83,9 & 83,4 & 75,7 & 81,4 & 82,8 & 79,9 & 81 & 84,3 & 80,9 & 81,4 \\
\hline \multirow{4}{*}{$\begin{array}{l}u \\
\text { U. } \\
\text { E }\end{array}$} & Total working time (h) & 780 & 910 & 1001 & 910 & 949 & 936 & 1041 & 955,5 & 1021 & 877,5 & 955,5 & 955,5 \\
\hline & Effective working time (h) & 650,5 & 647,5 & 790 & 615,5 & 762,5 & 695 & 642 & 453,5 & 648 & 644,5 & 811,5 & 542 \\
\hline & Net time of repetitive work & 484 & 501 & 626 & 495 & 628 & 435 & 475 & 368 & 525 & 523 & 576 & 364 \\
\hline & Saturation (\%) & 74,3 & 77,3 & 79,2 & 80,4 & 82,4 & 62,5 & 73,9 & 81 & 81 & 81,1 & 70,9 & 67,1 \\
\hline
\end{tabular}

Table 9

Intrinsic risk for repetitive movements for each task

\begin{tabular}{|c|c|c|c|}
\hline \multirow{2}{*}{\multicolumn{2}{|c|}{$\begin{array}{l}\text { TASK } \\
\text { Plantation of flower groups }\end{array}$}} & DX & IX \\
\hline & & \multicolumn{2}{|c|}{ Plantation of flower groups } \\
\hline \multirow{2}{*}{\multicolumn{2}{|c|}{ To delimitate groups }} & 19,1 & 14,6 \\
\hline & & 22,7 & 16,4 \\
\hline \multirow{2}{*}{\multicolumn{2}{|c|}{ To plant }} & 15,5 & 15,8 \\
\hline & & 17 & 12,5 \\
\hline \multicolumn{4}{|c|}{ Maintenance of flower groups } \\
\hline \multicolumn{2}{|c|}{ To remove flowers or dried leaves } & 21,5 & 14 \\
\hline \multicolumn{4}{|c|}{ Maintenance of the grass } \\
\hline \multicolumn{2}{|c|}{ To reap (automotive reaper) } & 11,5 & 11,5 \\
\hline \multicolumn{2}{|c|}{ To reap (self-propelled reaper) } & 11,4 & 11,1 \\
\hline \multirow{3}{*}{ To clean } & group of plants & 15 & 10,5 \\
\hline & isolated plants & 14,5 & 10,5 \\
\hline & edges & 14 & 18,5 \\
\hline \multicolumn{4}{|l|}{ Maintenance of path } \\
\hline \multirow{2}{*}{ To complete with sand } & Close Area. & 16,5 & 21 \\
\hline & Far Area & 17,5 & 17,5 \\
\hline \multicolumn{2}{|l|}{ To clean with the blower } & 11,5 & 6 \\
\hline To remove weeds & & 22 & 11,5 \\
\hline \multicolumn{4}{|c|}{ Pruning of trees and bushes } \\
\hline \multirow{2}{*}{ To prune trunk } & eight $<1 \mathrm{~m}$ & 21,5 & 17 \\
\hline & eight $>1 \mathrm{~m}$ & 19,7 & 13,2 \\
\hline \multicolumn{2}{|l|}{ To shape trunk } & 17,9 & 17,4 \\
\hline \multicolumn{4}{|l|}{ Several } \\
\hline \multirow{2}{*}{ Light digging } & Little vegetables & 16,5 & 7 \\
\hline & Big plants & 16,5 & 13 \\
\hline \multicolumn{2}{|l|}{ To irrigate with hose } & 21,5 & 10,5 \\
\hline \multicolumn{2}{|l|}{ To sweep } & 16 & 20 \\
\hline
\end{tabular}

As demonstrated in this table, for some tasks, some variants were defined. These variants are conditions that had different effects on the upper limbs, depending from the kind of requirements. For example, the requirement to clear a group of plants is really different from clearing the edges of a parterre.

After this, the monthly risk value was calculated as the arithmetic average of the intrinsic risk values of each task, weighted by the exposure time to each of them.
As the exposure time information for each of the identified variants was not available, the monthly risk value was enclosed in the value ranges. The maximum value matches the arithmetic average, weighted by the time, considering the variants with maximum intrinsic risk values. The minimum value matches the arithmetic average weighted by the time considering the variants of each task with minimum intrinsic risk values. 
The range of monthly risk values obtained in each park for the left and right upper limb are shown in the Figures 1, 2 and 3.

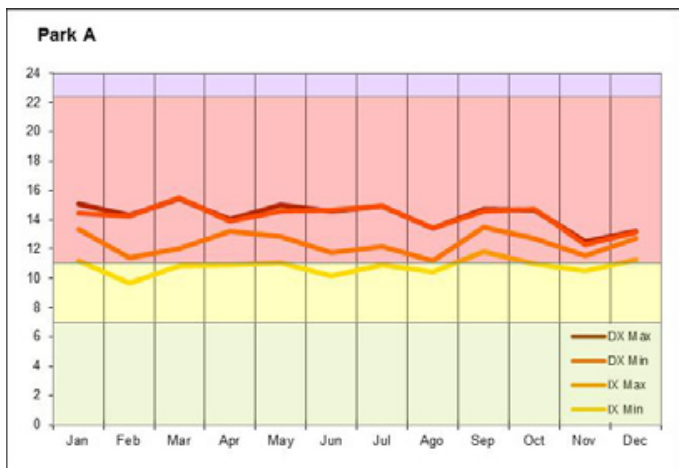

Figure 1 - Intrinsic risk level evolution of park A, year 2009

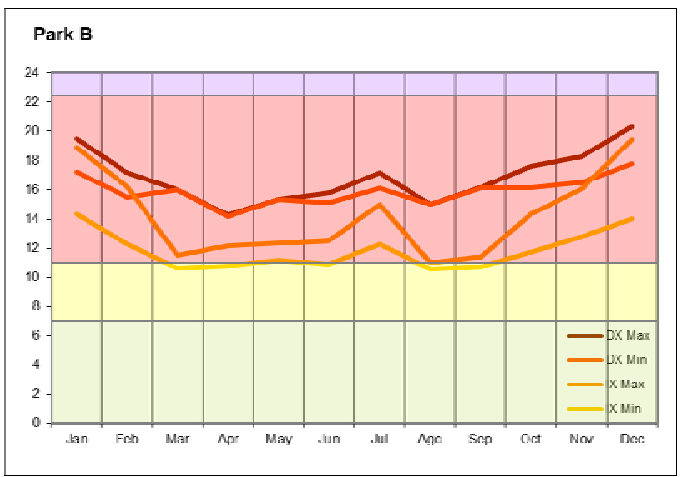

Figure 2 - Intrinsic risk level evolution of park B, year 2009

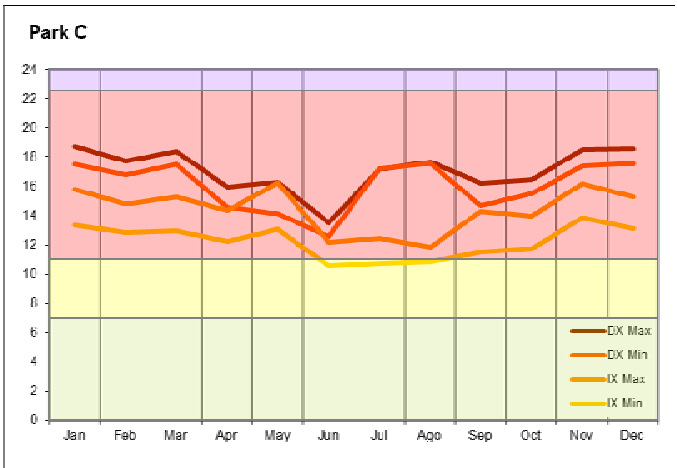

Figure 3 - Intrinsic risk level evolution of park C, year 2009

The right upper limb is the limb with greatest exposure in all parks. In Figure 4 the comparison be- tween the maximum values obtained in the three parks is shown.

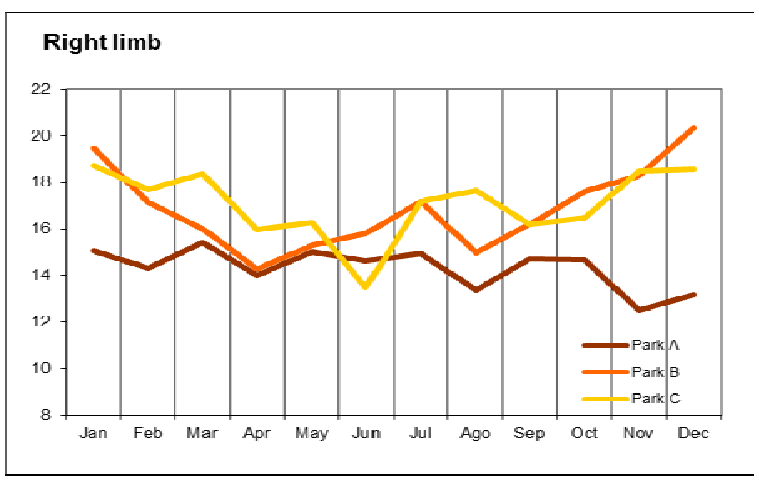

Figure 4 - Comparison of the evolution of real risk level evolution, year 2009

\section{Discussion}

The work of urban gardening is an activity that, even though it is accomplished in many cases with the support of machines and tools, it is intensively manual and characterized for repetitive tasks.

The kind of tasks that they have to accomplish and the necessary time that they dedicate to them follow an annual cycle pattern, marked by the vegetal cycle, similar to the major part of agriculture jobs in warm geographical areas, where the climate is distinguished by four seasons.

The major part of the tasks accomplished during the year requires a high biomechanical overload in the upper limbs; this causes significant risk to develop work-related musculoskeletal disorders.

In spite of the fact that all the kinds of gardening tasks are similar in all the parks, the features of the landscape design create differences in the necessary time of dedication to each task.

These differences in the temporal exposure pattern create the differences between the exposure risk levels between each park (see Figure 4). As noted in this figure, park A requires less requirements in the right upper limb than park $\mathrm{C}$. The main reason of this is that in park A they dedicate a high percentage of time on grass maintenance, which is a task with less requirements, as they use machines that help to keep adequate postures. In park $\mathrm{C}$, on the other hand, they use a higher percentage of time on the maintenance of hedges and bushes, a task where they need a higher movement frequency and more unnatural postures. 


\section{Conclusions}

From this pilot study conducted in three urban parks in Barcelona, it can be concluded that urban gardening tasks have a high level of requirements in the upper limbs. For this reason it is highly possible that a significant part of the working population will develop musculoskeletal disorders.

The analysis of the exposure to the biomechanical overload on upper limbs in gardening works is a complex task, mainly because it is an activity with a high percentage of variability and with annual cycle.

In this research we presented a methodology of analysis that allows us to get interesting information with the aim to create organizational measures related to the assignment of tasks, to the training of staff and to the recommendations of urban landscape design.

It is possible that if this research is extended to a higher number of parks with different design features, an analysis and simulation frame can be obtained, which can be useful to orientate organization and landscape design decisions in order for its maintenance.

\section{Acknowledgements}

The authors would like to thank Pep Llimona and Francesc Morales for their collaboration in providing administrative permissions and organizational data necessary to develop this study, and also warm thanks to Enrico Occhipinti and Daniela Colombini for their contributions, encouragement, and continuous support.

\section{References}

[1] I.M. Franck and D.M. Brownstone, Harvester's: Work Throughout History, Facts on File Publications, ISBN 0816014450, New York, 1987.

[2] D. Colombini and E. Occhipinti, Preventing upper limb workrelated musculoskeletal disorders (UL-WMSDS): new approaches in job (re)design and current trends in standardization, Applied Ergonomics, v. 37, issue 4, pp. 441-450, 2006.

[3] D. Colombini, A. Hernández and E. Álvarez-Casado, Repetitive movements of upper limbs in agriculture: set up of annual exposure level assessment models starting from OCRA checklist via simple and practical tools, Proceedings of the Agriculture Ergonomics Development Conference 2007, Kuala Lumpur, Malaysia, 2007.

[4] E. Álvarez-Casado, A. Hernández-Soto and D. Colombini, Repetitive movements of upper limbs in viticulture: set up of annual exposure level assessment models with OCRA checklist comparing with the first results of clinical data, Proceedings of the 17th Triennial Congress of the International Ergonomics Association, August 9-14, 2009, Beijing, China. Taiwan, ROC: International Ergonomics Association, 2009.

[5] E. Alvarez-Casado, A. Hernandez-Soto and S. Tello, Manual de evaluación para la prevención de trastornos musculoesqueléticos, Ed. Factors Humans, ISBN 978-84-6135617-1, Barcelona, 2009. 